\title{
AZ ÉRTÉKESÍTÉS- ÉS MÜKÖDÉSTERVEZÉS VÁLLALATI GYAKORLATÁNAK ÉRETTSÉGE EGY HAZAI KÉRDÖÍVES FELMÉRÉS TÜKRÉBEN
}

\author{
THE MATURITY OF THE CORPORATE PRACTICE OF SALES AND \\ OPERATIONS PLANNING - RESULTS OF A HUNGARIAN SURVEY
}

A cikk a Sales \& Operations Planning témakörét helyezi a vizsgálat középpontjába. Ez az ellátási lánc reálfolyamatainak taktikai szintű tervezése során alkalmazott szervezeti egyeztetési folyamat, melynek célja, hogy dinamikus újratervezési ciklusokon keresztül egyensúlyt teremtsen a tényleges kereslet, a rendelkezésre álló erőforrások és az általuk biztosítható kínálat között úgy, hogy támogassa az üzleti terv megvalósulását. Egy viszonylag új, elméleti szempontból érdekes, de a vállalati gyakorlat számára is fontos kérdéskörről van szó. Ennek ellenére a szerzők legjobb tudomása szerint még nem jelent meg magyar nyelven cikk a témakörben. Munkájuk egyik célja ezért az, hogy felhívják a figyelmet erre a területre. A másik cél, hogy egy komplex érettségi modell tükrében bemutassák a hazai vállalatok S\&OP gyakorlatát. A választott modell négy fő dimenzió mentén térképezi fel a vállalati gyakorlatot: a tervezési folyamat hatékonysága, eredményessége, a szervezeti/emberi felkészültség és az informatikai támogatottság. A tanulmány benchmarking lehetőséget teremtve ismerteti a mintában szereplő vállalatok gyakorlatának érettségét és fejlesztési javaslatokat fogalmaz meg.

\section{Kulcsszavak: Sales and Operations Planning, érettségi modell, benchmarking}

The article puts the topic of Sales \& Operations Planning at the centre of the study. It is a relatively new management solution, which is interesting from a theoretical point of view, but also important for corporate practice. Nevertheless, to the best of the authors' knowledge, no article on the topic has been published in Hungarian yet. One of the aims of their work, therefore, is to draw attention to this area. The other goal is to present the S\&OP practice of domestic companies in the light of a complex maturity model. The chosen model maps S\&OP practice of corporations along four main dimensions: the efficiency and effectiveness of the planning process, organizational/human readiness, and IT support. Creating a benchmarking opportunity, the study describes the maturity of the companies in the sample and makes suggestions in respect of further developing related practice and increase maturity.

Keywords: Sales and Operations planning, maturity model, benchmarking

\section{Finanszírozás/Funding:}

A szerzők a tanulmány elkészítésével összefüggésben nem részesültek pályázati vagy intézményi támogatásban.

The authors did not receive any grant or institutional support in relation with the preparation of the study.

\section{Szerzők/Authors:}

Dr. Gelei Andrea, egyetemi tanár, Budapesti Corvinus Egyetem, (andrea.gelei@uni-corvinus.hu)

Donáczi Katinka, supply chain analyst, 4flow, (katinkadonaczi@gmail.com)

A cikk beérkezett: 2019. 08. 23-án, javítva: 2020. 03. 04-én, elfogadva: 2020. 05. 25-én.

This article was received: 23. 08. 2019, revised: 04. 03. 2020, accepted: 25. 05. 2020.

$\mathrm{C}$ ikkünk a Sales \& Operations Planning (S\&OP), magyarul értékesítés- és müködéstervezés témakörét helyezi a vizsgálat középpontjába. A vállalati erőforrások tervezése mindig is kiemelt jelentőségü volt a vállalatok és ellátási láncaik versenyképessége szempontjából (Aquilano, Chase, Davis \& Davis, 1991; Stadtler \& Kilger, 2005), melyet a hazai szakirodalom is viszonylag széles körben tárgyalt (László, 1977; Tari, 1987; Chikán \& Demeter (szerk.), 1999; Koltai, Romhányi \& Tatay 2009; Vörös, 2018). Ugyanakkor maga az S\&OP, mint speciális tervezési, szervezési folyamat eddig nem került be a hazai szakmai közélet kutatott témakörei közé. Pedig a témakörben 
megjelent nemzetközi publikációk száma 2010-től jelentősen megugrott (Kristensen \& Jonsson, 2018).

Az S\&OP a vállalati tervezésen belül az ellátási lánc erőforrás-tervezésére fókuszál, mely felöleli a tervezett kereslet kielégítéséhez szükséges anyagi erőforrások és az ezek előállításához szükséges kapacitások iránti várható igény meghatározását. Ez a tervezés mindig is komoly kihívásokkal teli tevékenység volt. Az utóbbi időszak tendenciái - így pl. maga a globalizáció, s ezzel az összetett, földrajzilag is széttöredezett globális értékláncok létrejötte - tovább növelték e tervezési folyamat összetettségét. A Sales \& Operations Planning egy olyan viszonylag új tervezési és szervezeti egyeztetési folyamat, melynek célja, hogy támogassa ezt az összetett, ellátási lánc szintű tervezési folyamatot azzal a céllal, hogy egyensúlyt teremtsen a tényleges kereslet és a rendelkezésre álló erőforrások, illetve az általuk biztosítható kínálat között oly módon, hogy közben hatékonyan támogassa az üzleti terv megvalósulását.

Kutatások arra hívják fel a figyelmet (Lin, Hwang \& Wang, 2007; Thomé, Scavarda \& Suclla, 2012; Wagner, Ullrich \& Transchel, 2014; Vereecke, Vanderheyden, Baecke \& Van Steendam, 2018), hogy az S\&OP megfelelő alkalmazása révén a vállalatok a következő alapvető előnyöket realizálhatják:

- megbízható keresleti és azzal integrált erőforrásterv jön létre,

- megfelelő lesz a marketing- és promóciós kampányok támogatása, ennek eredményeképpen nő a termékek rendelkezésre állása, csökken a termékhiányos állapotok gyakorisága, magasabb lesz a vevőkiszolgálási színvonal, ezzel nő a vevői elégedettség és az árbevétel,

- az ellátási lánc erőforrásainak magasabb lesz a kihasználtsága, csökken a készletszint és a sürgősségi szállítások száma, így nő az ellátási lánc hatékonysága, csökkennek a tőke- és müködési költségek,

- fókuszálni lehet a nagyobb árréssel rendelkező termékekre/vevőkre,

- az ellátási lánc átláthatósága nő és ezzel a működési kockázatok csökkennek,

- végső soron pedig nő a befektetett eszközök megtérülése.

Az S\&OP témakörében több magyar nyelvü szakdolgozat is született már (Szalai, 2013; Pintácsi, 2017; Serfel, 2018; Donáczi, 2019), de az értékesítés- és müködéstervezés témakörében eddig szakcikk - legjobb tudomásunk szerint - még nem jelent meg magyar nyelven. Munkánk egyik alapvető célja ezért az, hogy a hazai kutatói közösség figyelmét felhívjuk erre a területre, témává tegyük azt. Másik kutatási célunk, hogy egy hazai felmérés segítségével bemutassuk vállalataink S\&OP gyakorlatának fejlettségét. Ez lehetővé teszi az erősségek, de a gyenge pontok azonosítását, és ezzel a fejlesztési prioritások kijelölését is. Cikkünkben ezért elsőként röviden értelmezzük a Sales \& Operations Planning fogalmát, elhelyezzük azt az ellátási lánc komplex erőforrás-tervezési rendszerében. Ezt követően, egy összetett érettségi modell segítségével, online kérdőíves felmérés tükrében ismertetjük a hazai vállalati gyakorlatot. Értékeljük a felmérés eredményeit, majd fejlesztési javaslatokat fogalmazunk meg.

\section{Az S\&OP mint az ellátási lánc erőforrás- tervezését támogató szervezeti folyamat}

A vállalatok hálózati működési modelljének térnyerésével az erőforrások tervezése jellemzően nem kezelhető hatékonyan egyetlen (lokális) vállalat szintjén. Az erőteljes nemzetköziesedés összekapcsolódva az intenzív kiszervezési és kihelyezési tevékenységgel összetett üzleti hálózatokat, benne komplex belső vállalati struktúrákat, ún. belső ellátási láncokat hozott létre (Gelei, 2009). Ezekben a belső ellátási láncokban a vállalati müködés hagyományosnak tekinthető funkcionális széttagoltsága és siló szemlélete földrajzi széttagoltsággal kapcsolódik össze, ami tovább nehezíti egy megbízható, integrált erőforrásterv létrehozását.

Az ellátásilánc-menedzsment irodalma jól ismeri az ún. ostorcsapáshatás jelenségét és az általa okozott problémát, amikor a müködésben egyszerre van jelen a csökkenő vevői elégedettséggel párosuló hiány és a felesleges készletek (Lee, Padmanabhan \& Whang, 1997; Kovács, 2011). Az ostorcsapáshatást generáló tervezési gyakorlatot szokás hagyományos utántöltési rendszernek nevezni (De Toni \& Zamolo, 2005). Legfontosabb jellemzője, hogy az ellátási folyamat minden szereplője önállóan tervez, az egyes tervek szisztematikus integrálására nem kerül sor, így szükségszerüen sérül a rendszerszintű optimum. Ez nem csak a független partnerek alkotta, külső ellátási láncban igaz, de a nemzetközi nagyvállatok belső ellátási láncaiban is.

A belső ellátási láncok siló szemlélete jelentős részben a nem megfelelöen összehangolt motivációs rendszerben gyökerezik, mely érdekellentéteket generál, és szinte lehetetlenné teszi egy valóban integrált, mindenki által elfogadott és követett feltételekre épülő terv kialakítását és megvalósítását. Tipikus probléma például, hogy az értékesítő kollégák jellemzően alul terveznek, hiszen alapvetően a tervek túlteljesítésében érdekeltek. De tervezési problémát generálhat az is, ha pl. új termék bevezetésénél a gyárak vezetői - saját erejük és befolyásuk erősítése érdekében - túlvállalják magukat. Nagy kapacitásbővítést vállalnak, melynek kihasználása aztán sokszor nem biztosítható az elvárt szinten. A rosszul összehangolt motivációs rendszer, kiegészülve a felső vezetés elkötelezettségének hiányával, hozzájárul a lokális optimumok kialakulásához, ami végső soron a vállalatok profitabilitását veszélyezteti.

Részben a siló szemlélethez kapcsolódó probléma, hogy az ellátási lánc egyes funkcionális (pl. disztribúciós vagy termelési) tervei leginkább a pénzügyi tervhez kapcsolódnak, de nem képesek kezelni az ellátási folyamatok belső összefüggéseit, és így fontos szinergiákról mondanak le.

A holisztikus megközelítés hiánya mellett jelentős probléma a tervezés statikus jellege is. Nincs kialakítva egy hatékony periodikus felülvizsgálati rendszer, ami megteremtené a lehetőségét annak, hogy a terv alapjául 
szolgáló feltevések megváltozása esetén a szükséges korrekciókat elvégezzék, a tervet hatékonyan újratervezzék. A tervezés nem tud proaktív lenni, csak nehézkesen reagál a kialakuló problémákra ( $\mathrm{pl}$. az eredetileg tervezett szintet el nem érő, vagy éppen az azt meghaladó keresletre). Ennek eredménye a tűzoltás, a nem megfelelő intézkedések meghozatala, ami adott esetben csak tovább növeli a bajt. Mindez végső soron termékhiányhoz, hosszú kiszolgálási időhöz, elégedetlen vevőkhöz, egyben magas - gyakran felesleges - készletekhez, túlórához, sürgős szállításokhoz, költségnövekedéshez, cash flow-problémákhoz, majd a profit csökkenéséhez vezethet (Barratt, 2004; Wagner et al., 2014).

A fenti problémákra ad egy lehetséges megoldást az ún. Sales \& Operations Planning. Az S\&OP fogalmának meghatározására több szerző is vállalkozott. Olhager, Rudberg és Wikner (2001) szerint az S\&OP a keresleti terv és az ellátási kapacitások összehangolását végző tervezési folyamat. Feng, D’Amours és Beauregard meghatározásában (2008, p. 189) ez kiegészül a tervezési időhorizont megjelölésével, amikor kiemelik, hogy az nem más, mint „egy havi szinten ismétlődő, számos funkció együttműködésével zajló taktikai szintű tervezési folyamat, mely 1-2 éves időhorizontot fed le". Ivert és Jonsson (2010) megfogalmazásában az S\&OP alapvető célja, hogy egyensúlyt teremtsen a kereslet és a kínálat között, konszenzust hozzon létre a működésben érintett funkciók és szereplők között, és egy közös, megvalósítható terv mellé állítsa őket. Ez utóbbi értelmezés kiemeli, hogy az S\&OP esetén a hangsúly a szervezeti koordinációs mechanizmusokon van, az ellátási lánc erőforrásterveinek összehangolásán, mely során kritikus az értékesítési egységek és az ellátási lánc szereplőinek együttműködése. Nem elsősorban magának a tervezésnek a szakmai tartalmáról van itt szó, mint inkább egy olyan platform létrehozásáról, mely megteremti a szervezeti lehetőségét a terv készítése során ennek a hatékony egyeztetési folyamatnak.

Természetesen az S\&OP elválaszthatatlanul összekapcsolódik a taktikai szintű erőforrás-tervezés módszertani folyamatával. Az értékesítés tervezésének, a DRP-nek (Distribution Requirement Planning) és az MRP-nek (Manufacturing Resource Planning) az összekapcsolására építve horizontálisan integrálja az erőforrás-tervezést (1. ábra).

Erre a taktikai szintű erőforrás-tervezésre ,ül rá” maga az értékesítés- és müködéstervezés, melynek alapvető célja, hogy biztosítsa az érintettek közötti egyeztetés lehetőségét és ezzel egy jól megalapozott, szinergikus üzleti terv létrehozását, majd megvalósítását. Összefoglalva, munkánkban az értékesítés- és működéstervezést az ellátási lánc reálfolyamatainak taktikai szintü tervezése során alkalmazott tervezési és szervezeti egyeztetési folyamatnak tekintjük, melynek célja, hogy dinamikus újratervezési ciklusokon keresztül egyensúlyt teremtsen a tényleges kereslet, a rendelkezésre álló erőforrások és az általuk biztosítható kínálat között oly módon, hogy támogassa az üzleti terv megvalósulását.

A Sales \& Operations Planning kialakításának története hosszú múltra tekint vissza, fejlődésében eltérő megközelítések vannak. Egyes szerzők hozzánk hasonlóan a termelési erőforrás-tervezési rendszerek (Manufacturing Resource Planning, ERP II) kontextusában tárgyalják azt (Oliver Wight, 2017). Mások az aggregált termeléstervezés (Aggregate Production Planning) szinonimájaként használták (Wagner, Ullrich, \& Transchel, 2014). A módszertan mindenképpen ez utóbbiból nőtte ki magát önálló koncepcióvá, de nem egyezik meg azzal. Mindkét esetben középtávú tervezésről van szó, de míg az aggregált termeléstervezés feladata fö termékcsoportok szintjén vizsgálni a termelési terv megvalósíthatóságát, az S\&OP tervezési folyamata ennél részletesebb, így jobban támogatja az operatív folyamatokat. Ráadásul az aggregált termeléstervezés alapvetően egy számítási módszertan (Singhal \& Singhal, 2007), míg az értékesítés- és működéstervezés egy szervezeti egyeztetési folyamat, mely természetesen a módszertani tervezés során használt matematikai-statisztikai és kapcsolódó kvalitatív elemzések eredményeit felhasználja. Fontos különbség van továbbá a két koncepció között a tervezés dinamikájában is. Mindkettő középtávú tervezés, de míg az előbbi jellemzően éves tervezés, melyet negyedévi frissítéssel használnak, az S\&OP folyamata sokkal dinamikusabb: a havi vagy akár heti szintü újratervezéseket ún. eseményalapú tervezési ciklusok is kiegészíthetik.

Az S\&OP helye az ellátási lánc tervezési mátrixában

\begin{tabular}{|c|c|c|c|c|c|}
\hline $\begin{array}{l}\text { Az ellátási lánc } \\
\text { alrendszerei }\end{array}$ & Beszerzés & Termelés & Disztribúció & Értékesítés & Információáramlás \\
\hline \multicolumn{6}{|l|}{ Tervezési időtáv } \\
\hline Hosszú táv & \multicolumn{4}{|c|}{ Stratégiai tervezés } & \multirow{2}{*}{$\begin{array}{l}\text { oda-vissza irányban } \\
\text { a két időtáv között }\end{array}$} \\
\hline Középtáv & \multicolumn{4}{|c|}{$\begin{array}{l}\text { Értékesités- és müködéstervezés } \\
\text { MRP - DRP - Értékesítés tervezése }\end{array}$} & \\
\hline Rövid táv & $\begin{array}{c}\text { Beszerzések } \\
\text { ütemezése }\end{array}$ & $\begin{array}{l}\text { Termelés } \\
\text { ütemezése }\end{array}$ & $\begin{array}{l}\text { Szállítások } \\
\text { ütemezése }\end{array}$ & $\begin{array}{c}\text { Rendelésfogadás és } \\
\text { kiszolgálás }\end{array}$ & $\begin{array}{l}\text { oda-vissza irányban } \\
\text { a két időtáv között }\end{array}$ \\
\hline
\end{tabular}

Forrás: Nemati, Madhoshi \& Safaei Ghadikolaei (2017, p. 4) 
Az S\&OP mint szervezeti egyeztetési folyamat több szakaszra bontható (2. ábra). Grimson és Pyke (2007) a folyamatot öt lépésre bontja:

1. A kereslet tervezése az értékesítés és marketing érdekeinek figyelembevételével. Résztvevők: értékesítés és marketing részleg, kiemelt vevők.

2. Az ellátási terv kialakítása, a disztribúciós, termelési és beszerzési igények taktikai szintű meghatározása. Résztvevők: disztribúciós, termelési és beszerzési tervezésért felelős személyek, kiemelt beszállító partnerek.

3. Integrációs szakasz vagy S\&OP értekezlet: egy döntés-előkészítő szakasz, ahol formálisan is ütköztetik a keresleti és ellátási terv számait és a mögötte meghúzódó üzleti feltételezéseket. Ezzel előkészítik egy kiegyensúlyozott, konszenzusos, integrált és ezért megvalósítható terv létrehozását. E konszenzus megtalálásában meghatározó jelentősége van az ún. üzleti feltételezések csomagjának (Business Assumption Package) (Oliva \& Watson, 2010), mely a keresleti és ellátásilánc-terv indító kombinációjából áll össze. Minél kedvezőbb képet mutat a kialakult üzleti feltételezéseknek ez a csomagja, annál könnyebben tudnak majd megállapodásra jutni az érintettek. $\mathrm{Az}$ értekezleten kialakult megoldást elöterjesztik a felső vezetésnek. Résztvevők: a stratégiai, értékesítési és marketingtervezésért, valamint az ellátási lánc tervezéséért felelős szakemberek és pénzügyi terület szakértői.

4. Felsővezetői döntés szakasza: Az összehangolt tervek és a mögöttes feltételezések prezentálása a vezetőknek, majd döntés az integrált tervről.

5. Teljesítménymérés és tanulás szakasza: Ekkor történik meg az S\&OP folyamat eredményességének vizsgálata, hiszen a tervek teljesülése, az elért teljesítmény mérése, a tanulságok levonása és az erre épülő visszacsatolás nélkülözhetetlen eleme a folyamatos fejlödésnek.
Wagner és szerzőtársai (2014) ezt a szakaszolást kiegészítik egy olyan lépéssel, mely az induló terv újratervezése. Ez az adatgyüjtés lépése, mely során a vállalati IT-rendszerekben elérhető adatokból képeznek riportokat (pl. aktuális eladási adatok, termelési és készletmennyiségek) és KPI-okat (key performance indicator), melyek segítségével a pillanatnyi teljesítményt értékelni, az előjelzési hibákat, az aktuális termelési rátákat elemezni tudják. Ennek a lépésnek a jelentősége nyilvánvaló, ha az S\&OP-re nem mint egy statikus folyamatra gondolunk, hanem azt a gördülő tervezés egy konkrét, igen dinamikus megoldásaként értelmezzük. Már korábban is hangsúlyoztuk, hogy az S\&OP nem egyszeri folyamat, lényegéhez tartozik az induló terv folyamatos, szisztematikus felülvizsgálata. Ezen kívül a fejlett S\&OP megoldások képesek ún. eseményalapú újratervezésre is. Természetesen ilyen esetben a folyamat első két szakasza lerövidül, és az egyeztetések központjában is maga az esemény (pl. versenytárs előre nem látott akciója, a koronavírus okozta gyökeres változás a vevői keresleti mintázatokban) és az általa kiváltott problémakör (pl. a tervezett kereslet jelentős elmaradása vagy éppen megugrása) áll (Grimson \& Pyke, 2007; Oliva \& Watson, 2010).

Az S\&OP logikus és egyszerünek tűnő folyamat, mégis sok vállalat számára komoly kihívást jelent. A felsővezetői elkötelezettség mellett kiemelt jelentösége van a sikerben a folyamat informatikai támogatásának. A hagyományos ERP-rendszerek alapvetően nem az ellátási lánc kiszolgálására jöttek létre. Az ún. fejlett tervezési és ütemezési rendszerek (Advanced Planning and Scheduling Systems, APS-rendszerek) olyan ERP-rendszerek, melyek képesek a hatékony S\&OP folyamat támogatására (Stadtler \& Kilger, 2005; Genin, Thomas \& Lamouri, 2007) hiszen:

- a korábbi ERP-rendszerekhez képest több a tervezésben használt matematikai-statisztikai módszertant, informatikai algoritmust foglalnak magukban,

- képesek a vezetői döntéseket gyors szimulációt biztosító eszköztárral támogatni,

- hatékony adatvizualizációs megoldásokat tartalmaznak, ezzel is támogatva a gyakori újratervezési folyamatot,

Az S\&OP folyamat mögötti tervezés módszertani lépései

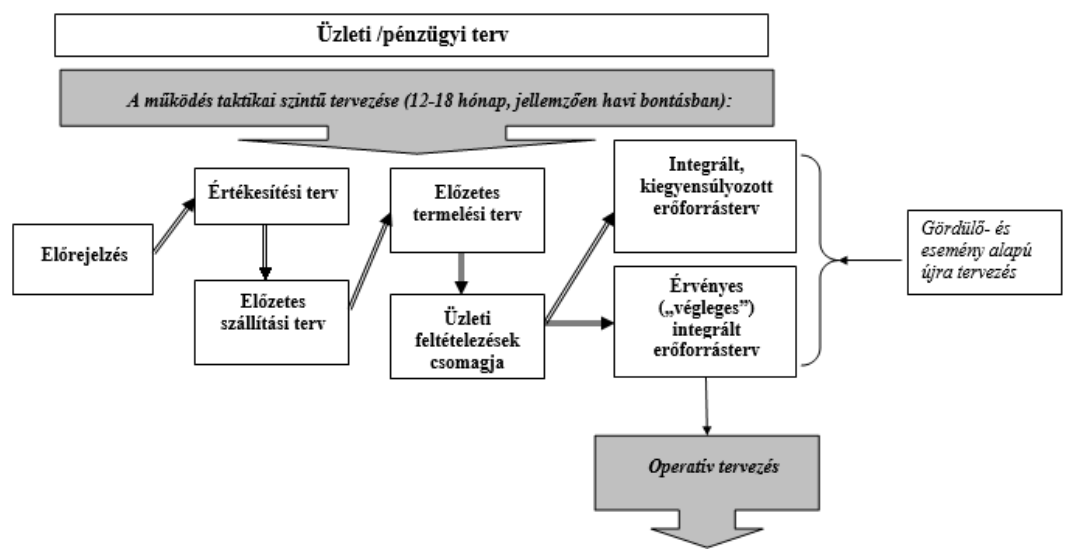


- integráltságuk, összehangoltságuk foka a korábbiakhoz képest magasabb - adatazonosság, valós idejü, zökkenőmentes információáramlás valamennyi érintett szereplő között (Ivert \& Jonsson, 2010).

Az S\&OP folyamat az erőforrás-tervezés integrálását szervezeti és informatikai eszközökkel is kell, hogy támogassa. Sikere szempontjából ugyanakkor fontos, hogy ne csak a terv integrációja, de arra építve valós együttmüködés is létrejöjjön. Ennek az együttműködésnek az alkotóeleme a felsővezetői elkötelezettség, az együttműködő szervezeti kultúra, ami bizalomból, kölcsönösségből, nyitottságból és őszinte kommunikációból áll (Barratt, 2004).

\section{Az S\&OP folyamat érettségi modelljei}

Az értékesítés- és működéstervezés természetesen több fejlettségi szinten valósulhat meg. A különféle érettségi szinteket ún. érettségi modellekkel írhatjuk le. Egy érettségi modell a releváns tényezők egy jól strukturált rendszere, ami megadja a hatékony és eredményes folyamat elemeit, lényegi jellemzőit, majd azokat különféle fejlettségi szakaszokhoz rendeli. A különböző szakaszok határvonalán azt is bemutatják, hogy mi szükséges ahhoz, hogy az egyik érettségi szakaszból egy következőbe juthassunk (Wendler, 2012). Mint említettük, ezeknek az érettségi modelleknek a használata a vállalatok számára benchmarkingot tesz lehetővé. Előnyös, mert hatékony módját adják annak, hogy saját meglévő gyakorlatukat a modell dimenziói mentén feltérképezzék és annak fejlettségét mérjék (Vereecke et al., 2018).

A szakirodalomban több olyan cikket találtunk, mely az egyes érettségi modellek mentén értékeli egy (Seeling, Scavarda, Thomé \& Hellingrath, 2018), esetenként több (Pedroso, da Silva \& Tate, 2016; Ávila, Lima, Moreira, Pires \& Bastos, 2018; Danese, Molinaro \& Romano, 2018) vállalat S\&OP folyamatának fejlettségét. Az esettanulmányok elönye, hogy egy-egy vállalati gyakorlat mélyebb megismerésére adnak lehetőséget, s ez elősegíti az ágazati, méretből fakadó és egyéb kontextuális tényezők hatásának jobb megértését. Ugyanakkor a benchmarking irodalom is hangsúlyozza, hogy az általános benchmarking is értékes, tehát a vállalattól akár jelentős mértékben különböző cégek gyakorlatának megismerése és a saját megoldások ennek tükrében történő értékelése is fontos (Tenner \& DeToro, 1998). Ilyen célt szolgál adott müködési gyakorlat kérdőív segítségével történő feltérképezése. Az S\&OP területén ez sokkal ritkább, de ilyen megoldást is találtunk (Vereecke et al., 2018). Mi is ezt a megoldást választottuk, amikor a kérdöíves adatfelvétel mellett döntöttünk. Munkánk célja, hogy egy komplex érettségi modell mentén, kérdöíves felmérés tükrében bemutassuk a hazai vállalatok S\&OP gyakorlatának jellegzetességeit, értékeljük annak fejlettségét. Eredményeinket más vállalatok fejlesztési céllal hasznosíthatják.

A szakirodalomban több S\&OP érettségi modellt találtunk. Meg kell jegyeznünk ugyanakkor, hogy az elmúlt években megjelentek olyan kapcsolódó érettségi modellek is, melyek az összetett értékesítés- és müködéstervezés folyamatának egy-egy elemére fókuszáltan fogalmaznak meg a vállalati gyakorlat fejlettségének mérésére alkalmas modelleket. Így például Vereecke és szerzőtársai (2018) az összetett tervezési folyamat első elemére, a kereslet tervezésének folyamatára dolgoztak ki önálló érettségi modellt.

Kérdöívünk kidolgozására a szakirodalomban rendelkezésre álló átfogó Sales and Operations Planning érettségi modellek áttekintése után került sor. Az S\&OP kapcsán több ilyen érettségi modellt is találtunk. Az elsőt az Aberdeen Group, egy tanácsadó cég dolgozta ki (idézi Grymson \& Pyke, 2007). Ezt követően Lapide (2005), majd Grimson és Pyke (2007) publikált egy-egy érettségi modellt. Ezeket Wagner és szerzőtársai (2014) összegezték és továbbfejlesztették, létrehozva egy igen összetett érettségi modellt, melyre más empirikus kutatások is építettek már (pl. Danese et al., 2018). A következőkben ismertetjük a Wagner és szerzőtársai által jegyzett összefoglaló modellt (röviden nevezzük Wagner-féle modellnek), melyet kérdőíves felmérésünkben mi is használtunk.

A modell a következő érettségi szinteket azonosítja (megjegyezzük, hogy az eredeti számozás $0-5$ közötti szinteket azonosít, a félreértések elkerülése miatt mi ez $1-6$ érettségi skálaként számoztuk, és jelenítettük meg a kérdőívünkben és az elemzésben):
1. szint: Fejletlen,
2. szint: Kezdetleges,
3. szint: Reaktív,
4. szint: Konzisztens,
5. szint: Integrált,
6. szint: Proaktív.

Az 1. szint, ahol még nem jelenik meg a tervezési folyamat ellátási szintü integrálásának igénye, míg a legmagasabb, 6. szinten lévő vállalatok már nem csak a vállalat belső ellátási láncának szintjén, de külső, független partnerekkel is igyekeznek a tervezést összehangolni, proaktív, problémamegelöző módon.

Walter és szerzőtársai mind a hat szinten négy fö értékelési dimenziót azonosítottak: a szervezeti, vezetési folyamat hatékonyságát, a folyamat eredményességét, a személyek és szervezet kapcsolatát az egyeztetési folyamatban és a támogató információs technológiát. Az egyes értékelési dimenziók konkrét szempontjai a következők:

\section{A folyamat hatékonysága}

Három fö szempontot hasonlít össze ez az értékelési dimenzió. A tervezési folyamat szabályozottságának fokát (kiemelik az S\&OP magas szabályozottsági fokának fontosságát), a szükséges információkkal való ellátottság, lefedettség mértékét és a folyamat összehangoltságát, mindenekelött az információmegosztással kapcsolatos szervezeti képességeket.

\section{A folyamat eredményessége}

Olyan jellemzőket foglal magába, amelyek azt írják le, miként integrálják és hozzák összhangba a tervezés során a különböző részterveket. Ilyen a tervezésbe fektetett energia és idő, amit jelentős mértékben befolyásol a szükséges információk előkészítettségének mértéke és megosztásuk kiterjedtsé- 
ge. A megbeszélések, egyeztetések hatékonysága, ami azok ütemezésének és strukturáltságának szintjétől függ. Végül a teljesítménymérés, azaz mennyire képes a vállalat a megfelelő KPI-ok definiálására, mérésére, melyek révén magának az S\&OP folyamatnak az eredménye megragadható.

\section{Szervezet és emberek}

Szerepek és felelősségi körök tisztázottsága a tervezési folyamatban, támogató szervezeti struktúra létrehozása, elkötelezettség és felsővezetői támogatás jelenléte. A személyek és szervezet dimenzió kapcsán fontos, hogy a keresztfunkcionális S\&OP csapat összes tagját fel kell készíteni a megfelelő módszertanok alkalmazására. Kiemelten fontos a részt vevő emberek attitüdjének fejlesztése, leginkább együttműködő készségüknek és nyitottságuknak a növelése.

\section{Információs technológia}

Az alábbi jellemzőket foglalja magában: alkalmazott IT-rendszerek és azok funkcionalitásai (a kereslet és az erőforrás-kínálat szinkronizálását támogató módszerek, algoritmusok és azok összehangolása), az adatalapú integráció foka (az adatok, információk megosztásának szintje alrendszerek, szervezeti egységek és vállalatok között).

$\mathrm{Az}$ egyes értékelési dimenziókat és azok szempontrendszerének érettségi szintenként történő részletesebb kibontását a Melléklet tartalmazza.

Ezt a modellt képeztük le kérdőívünkben. A modell számára releváns változók döntő többségét $1-6$ skálán mértük ( 1 = legkevésbé jellemző $\rightarrow 6=$ leginkább jellemző), ami lehetővé tette a kérdésekre adott válaszok érettségi szintekhez történő közvetlen hozzárendelését. A kérdőív kidolgozásánál megvizsgáltuk, hogy a modellben szereplő egyes konkrét értékelési szempontok a különböző érettségi szinteken hogyan jelennek meg és változnak. Megkerestük a modellnek azt a fogalmát, amire egy kérdőívben rá lehet kérdezni és értékelni is lehet azt egy hatfokú skálán. A modell operacionalizálása a kérdőívben részletesen is megtekinthető az alábbi linken: https://forms.gle/xyoBBYwQdvr7eWW59

\section{A kérdőíves felmérés eredményeinek bemutatása}

A kérdöív lekérdezése online módon történt. A kérdöív linkjét a Magyar Logisztikai, Beszerzési és Készletezési Társaság hírlevélben küldte meg tagságának, de a kérdőívet közvetlenül is kiküldtük egy 270 címes vállalati listára. Összesen 33 kitöltött kérdőívet gyüjtöttünk, ami alacsony válaszadási hajlandóságot mutat. Ennek meghatározó oka megítélésünk szerint a kérdöív hossza és összetettsége, ami következett a Wagner-féle modell átfogó és komplex jellegéből. Kérdőívünk három kérdéscsoportból állt:

- a demográfiai elemzés során rákérdeztünk a kitöltő cég méretére, iparági besorolására, exportteljesítményére, tulajdoni formájára,

- a kitöltő szakmai felkészültségére vonatkozó kérdések: beosztás, szakterület, tapasztalat, iskolai végzettség,
- az érettségi modellre vonatkozó kérdések a négy értékelési dimenzió mentén a következők voltak: folyamathatékonyság (21-30. kérdések), a folyamat eredményessége (31-36. kérdések), személyek és szervezet (37-41. kérdések) és információs technológia (42-46. kérdések).

Mint azt a 3. ábra is mutatja, mintánkban felülreprezentáltak a nagyvállalatok. Ezt azért nem tartjuk problémának, mert bár az S\&OP minden vállalat esetén hasznos eszköz, pozitív hatását legerőteljesebben a nagyvállalatoknál tudja kifejteni, ahol a méret mellett a földrajzi széttagoltság is nehezíti az integrált tervezést és az ehhez szükséges intenzív, nyílt kommunikációt.

3. ábra

A minta megoszlása a vállalatok mérete szerint $(\mathrm{N}=33)$

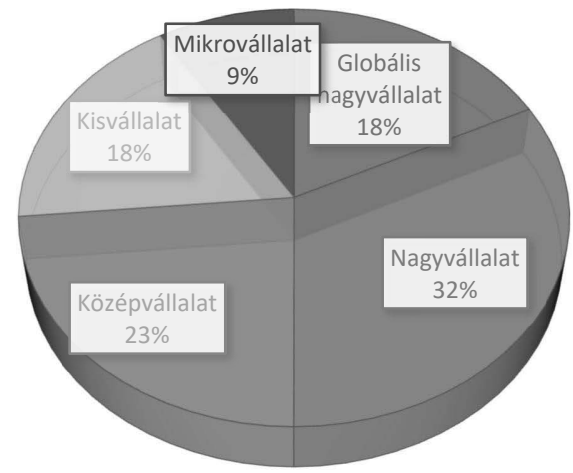

Forrás: saját szerkesztés

Tulajdonosi szempontból fontos, hogy a minta 48,48\%-a magyar magántulajdonban lévő vállalat, 33,33\%-a külföldi résztulajdonnal is bíró magánvállalat. Összesen a minta 9,09\% sorolható a teljesen külföldi tulajdonban lévő vállalati kategóriába, mint ahogyan állami vagy önkormányzati tulajdonba is a kitöltő cégek 9,09\%-a tartozik. Válaszadóink iparági háttere igen színes. Legnagyobb részesedéssel bírnak az élelmiszeripari vállalatok (16\%), a kereskedelmi és jármüipari cégek (15-15\%). A vállalatok 12\%-a a szolgáltató szektorba tartozik. Mind az építőipar, a szállítási - raktározási, postai és távközlési szolgáltatások, mind a gépipar 9-9\%-os részesedéssel bír. Találhatóak továbbá feldolgozóipari ( $6 \%$ ), fémipari, vegyipari és nyomdaipari (3-3\%) vállalatok is a kitöltők között.

A válaszadók döntő többsége felsővezetői pozíciót tölt be vállalatánál, 28\% ügyvezető igazgatói, 13\% igazgatói, további $25 \%$ osztályvezetői beosztásban vett részt felmérésünkben. A kitöltők jellemzően a logisztika, marketing/ kereskedelem és pénzügy szakterületeken dolgoznak, de érkezett válasz termelési és törzskari részről is. Mivel a felsorolt szakterületek mindegyike érintett az értékesítés- és müködéstervezés folyamatában, ezért a válaszok relevánsak és értékelhetők. A kitöltők jelentős szakmai tapasztalattal rendelkeztek a kérdéskörről, hiszen átlagos munkával töltött éveik száma 20, míg a jelenlegi vállalatnál eltöltött átlagos idejük 14 , az adott beosztásban pedig 
9 év volt. Mind a felső vezetők magas aránya, mind a nagy munkatapasztalat növeli eredményeink megbízhatóságát.

A következőkben a Walter-féle modell négy dimenziója és azok értékelési szempontjai szerint bemutatjuk eredményeinket. Elsőként a mintában szereplő valamennyi vállalatot összefoglaló jelleggel értékeljük a Wagner-féle modell négy fö dimenziója mentén (4. ábra). Ezt követően ismertetjük, hogy az egyes dimenziók értékelési szempontjai szerint a vállalatok hova helyezték magukat az érettségi modellben (1-4. táblázat). Az 5. ábrán valamenynyi dimenzióhoz tartozó értékelési szempontot együttesen mutatjuk be, végül a hazai kutatás eredményeit összevetjük a Wagner és szerzőtársainak saját felmérésének eredményével (6. ábra).

A 4. ábra a kérdőívet kitöltő 33 vállalatról mutat összképet a Walter-féle S\&OP érettségi modell négy fő dimenziója mentén. (Természetesen a felmérés a vizsgált vállalatok állapotát értékeli. Az egyes állapotokat jelző pontok összekötésére a 4. ábrán csak azért került sor, mert így a vállalatok adott érettségi szempont szerinti fejlettsége könnyebben megállapítható. Több értékelési dimenzió hasonló szintű fejlettsége esetén ugyanis az egyes pontok lefedhetik egymást. Ilyen esetben a pontok közötti öszszekötő vonalak segítenek a pontos érték, azaz fejlettségi szint azonosításában.)

A 4. ábra alapján összefoglaló jelleggel megállapíthatjuk, hogy a felmérésben szereplő hazai vállalatok S\&OP folyamata a négy értékelési dimenzióban jelentős eltéréseket mutat. A tervezési folyamat hatékony szervezése és a folyamatot támogató szervezeti és emberi tényezők tekintetében a leginkább kiegyensúlyozott a mintában szereplő cégek tervezési gyakorlata. Az egyes vállalatok között legnagyobb eltéréseket az értékesítés- és müködéstervezés informatikai támogatottságában látjuk. E tekintetben egyszerre vannak jelen a hazai gyakorlatban a legfejlettebb megoldások és az IT-támogatás szinte teljes hiánya. Aggasztó, ahogy a kitöltő vállalati szakemberek értékelték a tervezési folyamat eredményességét, mely a vizsgált dimenziók közül a legalacsonyabb érettségi szintet mutatja.

A következőkben a modell négy dimenziója és azok értékelési szempontjai mentén mutatjuk be eredményeinket.

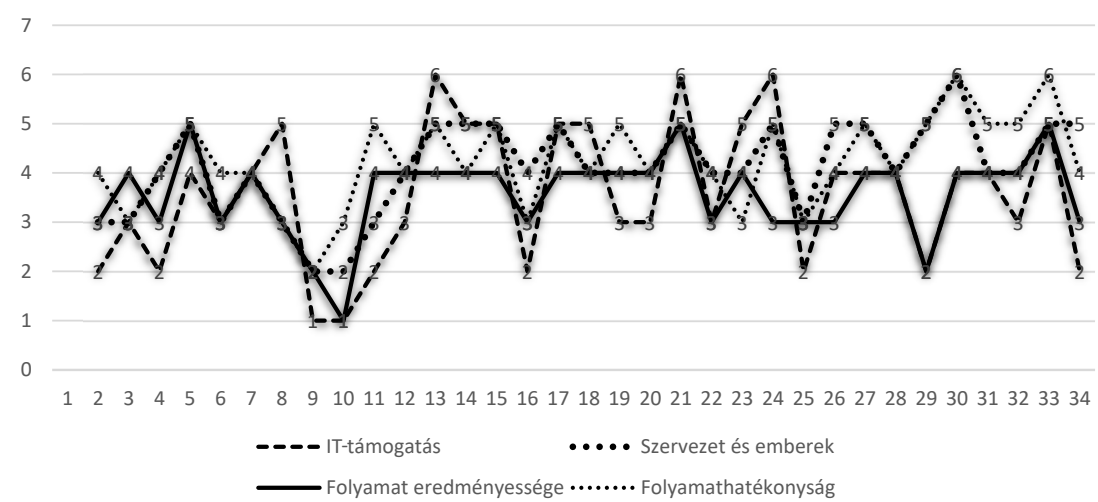

A mintában szereplő cégek érettsége a folyamathatékonyság dimenzióban $(\mathrm{N}=33)$

\begin{tabular}{|c|c|c|c|c|c|c|c|c|c|}
\hline \multirow[b]{2}{*}{$\begin{array}{l}\text { Minta } \\
\text { egésze }\end{array}$} & \multirow[b]{2}{*}{ Változók } & \multicolumn{6}{|c|}{$\begin{array}{c}\text { Adott fejlettségi szinthez tartozó vállalatok } \\
\text { száma (db) a mintában (ahol } 1 \text { a legkevésbé } \\
\text { érett, míg } 6 \text { a legfejlettebb gyakorlatot } \\
\text { mutatja) }\end{array}$} & \multicolumn{2}{|c|}{ Minta egésze } \\
\hline & & 1 & 2 & 3 & 4 & 5 & 6 & $\begin{array}{c}\text { Attlagos } \\
\text { fejlettségi } \\
\text { szint }\end{array}$ & Szórás \\
\hline \multirow{10}{*}{ 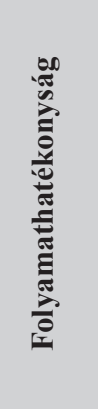 } & Folyamat szabályozottsága & 3 & 2 & 8 & 4 & 12 & 4 & 4,0 & 1,5 \\
\hline & SKU-kra való kiterjedtség & 1 & 4 & 8 & 9 & 7 & 4 & 3,9 & 1,3 \\
\hline & Átfogó kapacitástervezés & 1 & 3 & 7 & 5 & 10 & 7 & 4,2 & 1,4 \\
\hline & Promóciók, árváltozások tervezése & 1 & 5 & 7 & 9 & 8 & 3 & 3,8 & 1,3 \\
\hline & Életciklus-elemzés & 0 & 2 & 11 & 6 & 8 & 6 & 4,2 & 1,3 \\
\hline & Erőfeszítések a kereslet és kínálat kiegyenlítésére & 0 & 1 & 4 & 6 & 14 & 8 & 4,7 & 1,1 \\
\hline & Összhang pénzügyi tervezéssel & 0 & 3 & 2 & 7 & 10 & 11 & 4,7 & 1,3 \\
\hline & Szervezeti egységek közötti együttműködés & 0 & 1 & 1 & 9 & 14 & 8 & 4,8 & 1,0 \\
\hline & Releváns külső szereplők bevonása & 4 & 7 & 7 & 7 & 7 & 1 & 3,3 & 1,4 \\
\hline & Kockázatok kezelése & 1 & 3 & 5 & 9 & 11 & 4 & 4,2 & 1,3 \\
\hline
\end{tabular}




\section{Folyamathatékonyság}

Elsőként az S\&OP folyamathatékonyságát megragadó jellemzőkre adott válaszok gyakoriságait mutatjuk be, de jelezzük az adott értékelési dimenzió változói esetén a minta átlagos érettségi szintjét és annak szórását is. Megállapíthatjuk, hogy mintánkban a legmagasabb érettségi szintet a szervezeti egységek közötti együttműködés kapta $(4,8)$, de ezzel közel azonos fejlettségi szinten vannak a kereslet és kínálat összehangolására $(4,7)$, valamint a pénzügyi tervvel való összhang megteremtésére $(4,7)$ tett vállalati erőfeszítések. Legalacsonyabb szintủ a külső szereplők tervezésbe történő bevonásának gyakorlata $(3,3)$. Megállapítható továbbá, hogy komoly hiányosságok találhatók a jelenlegi tervezési folyamatban a promóciók és árváltozások figyelembevételében $(3,8)$, a tétel (SKU) szintủ tervezésben $(3,9)$, valamint a tervezési, összehangolási folyamat szabályozottságában $(4,0)$. Ezeket jelentősen nem meghaladva, közepesnél alig fejlettebb szintủ az átfogó kapacitástervezés, a tervezés során az életciklus figyelembevétele, valamint a kockázatok kezelésének hazai gyakorlata $(4,2)$ (1. táblázat).

\section{A folyamat eredményessége}

Ehhez a dimenzióhoz öt értékelési szempont tartozik (2. táblázat). Látható, hogy az átlagértékek alapján valamennyi értékelési szempont esetén a négyes szint alatt teljesítenek a mintában szereplő vállalatok. A legmagasabb érettségi szintet a tervezési folyamat teljesítményének mérése $(3,8)$ ért el. Igaz, itt a legnagyobb a szórás is. E szempont alapján mintánkban 11 olyan vállalat van, akik ötös fejlettségi szinten vannak. Söt, három cég a legfejlettebb, hatos érettségi szintü gyakorlattal rendelkezik. A leggyengébb eredményt a szervezeti és pénzügyi összehangoltság $(3,4)$ mutatja. E szempont szerint a mintában szereplő vállalatok majdnem 64\%-a hármas, vagy négyes érettségi szinten található. Az S\&OP folyamat eredményességének dimenzióját mérő többi értékelési szempontnál is azt látjuk, hogy a minta vállalatai alapvetően közepes érettségi szinten vannak.

\section{Szervezet és emberek}

Az eredmények ebben az értékelési dimenzióban is nagy szórást mutatnak. Találunk olyan változót, mely közepes

A mintában szereplő cégek érettsége a folyamat eredményessége dimenzióban $(\mathrm{N}=33)$

\begin{tabular}{|c|c|c|c|c|c|c|c|c|c|}
\hline \multirow[b]{2}{*}{$\begin{array}{l}\text { Értékelési } \\
\text { dimenzió }\end{array}$} & \multirow[b]{2}{*}{ Változók } & \multicolumn{6}{|c|}{$\begin{array}{c}\text { Adott fejlettségi szinthez tartozó vállalatok } \\
\text { száma (db) mintánkban (ahol } 1 \text { a legkevés- } \\
\text { bé érett, míg } 6 \text { a legfejlettebb gyakorlatot } \\
\text { mutatja) }\end{array}$} & \multicolumn{2}{|c|}{ Minta egésze } \\
\hline & & 1 & 2 & 3 & 4 & 5 & 6 & $\begin{array}{l}\text { Atlagos } \\
\text { fejlettségi } \\
\text { szint }\end{array}$ & Szórás \\
\hline \multirow{5}{*}{ 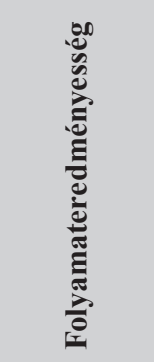 } & Tervezés automatizáltsága & 3 & 4 & 6 & 13 & 7 & 0 & 3,5 & 1,2 \\
\hline & Információ megosztottsága & 1 & 4 & 8 & 14 & 5 & 1 & 3,6 & 1,1 \\
\hline & Tervek újratervezése & 4 & 2 & 5 & 16 & 5 & 1 & 3,6 & 1,3 \\
\hline & A tervezés teljesítményének mérése & 5 & 2 & 5 & 7 & 11 & 3 & 3,8 & 1,6 \\
\hline & KPI szervezeti és pénzügyi összehangoltsága & 1 & 5 & 12 & 9 & 6 & 0 & 3,4 & 1,1 \\
\hline
\end{tabular}

Forrás: saját szerkesztés

A mintában szereplő cégek érettsége a szervezet és emberek dimenzióban $(\mathrm{N}=33)$

\begin{tabular}{|c|c|c|c|c|c|c|c|c|c|}
\hline \multirow[b]{2}{*}{$\begin{array}{l}\text { Értékelési } \\
\text { dimenzió }\end{array}$} & \multirow[b]{2}{*}{ Változók } & \multicolumn{6}{|c|}{$\begin{array}{c}\text { Adott fejlettségi szinthez tartozó vál- } \\
\text { lalatok száma (db) mintánkban (ahol } \\
1 \text { a legkevésbé érett, míg } 6 \text { a legfejlet- } \\
\text { tebb gyakorlatot mutatja) }\end{array}$} & \multicolumn{2}{|c|}{ Minta egésze } \\
\hline & & 1 & 2 & 3 & 4 & 5 & 6 & $\begin{array}{l}\text { Atlagos } \\
\text { fejlettségi } \\
\text { szint }\end{array}$ & Szórás \\
\hline \multirow{5}{*}{ 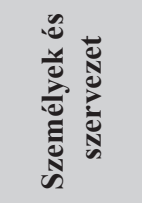 } & Tervezési szerepek, felelősségi körök definiáltsága & 0 & 1 & 5 & 11 & 9 & 7 & 4,5 & 1,1 \\
\hline & Tervezés szervezeti támogatottsága & 3 & 12 & 0 & 7 & 10 & 1 & 3,4 & 1,5 \\
\hline & Tervezésért felelősségre vonhatóság & 2 & 3 & 11 & 6 & 7 & 4 & 3,8 & 1,4 \\
\hline & Dolgozók tervezési szakértelme, fogékonysága & 0 & 1 & 5 & 14 & 10 & 3 & 4,3 & 0,9 \\
\hline & Felsővezetői támogatás és elkötelezettség tervezésért & 0 & 1 & 3 & 10 & 10 & 9 & 4,7 & 1,1 \\
\hline
\end{tabular}


érettségi szintű vállalati gyakorlatot tükröz (pl. a tervezés szervezeti támogatottsága). Meglepő, hogy csupán egy helyen jelölték meg a válaszadók, hogy létezik külön S\&OPért felelős osztály, felelős vezetővel, aki az egész ellátási láncon belül koordinálja a tervezést. A legtöbb cégnél tehát nincs ilyen szervezeti egység, legfeljebb a folyamatért felelős személy. E dimenzió többi értékelési szempontjában viszonylag fejlett a mintában szereplö vállalatok gyakorlata. 4,7-es átlagértékkel rendelkezik pl. a felsővezetői támogatás és elkötelezettség, de a tervezési szerepek és felelősségi körök definiáltsága szerint is viszonylag fejlettnek mondhatjuk a hazai gyakorlatot (átlagérték 4,5). Ennél a változónál a maximális 6-os szintet az a vállalat érhette el, akinél egyértelmúek a tervezéssel kapcsolatos feladatok, kapcsolódó szerepek, felelősségi körök és azokat sikeresen át is ültették a szervezetben (3. táblázat).

\section{IT-támogatás}

Felmérésünk szerint a vállalatok érettsége ebben a dimenzióban igen eltérö, összességében a legalacsonyabb. Viszonylag fejlett gyakorlattal rendelkeznek a cégek a tervezési adatok elérhetőségében (4,4-es átlag). Kimondottan alacsony fejlettségü viszont az integrált tervezést támogató szoftverek alkalmazása $(2,9)$. A kitöltő cégek 36\%-a egyáltalán nem rendelkezik ilyen szoftverrel. Ez az értékelési szempont egyben a teljes modellnek mind a négy értékelési dimenziója tekintetében is a legalacsonyabb érettségi szinten van. A többi értékelési szempont a 3,4-4,0 átlag értékek között mozog, azaz közepesen fejlettnek tekinthető (4. táblázat). átfogó jellegét és a promóciók, árváltozások tervezését. A tervezési folyamat leggyengébb pontja a fontos külső partnerek bevonása a tervezésbe.

A szervezet és emberek értékelési dimenzióban a felsővezetői elkötelezettség a legmagasabbra értékelt szempont. Viszonylag jónak értékelik a cégek a tervezési és felelősségi köröket, azok egyértelmüségét és a dolgozók szakértelmét is. Ennek ellenére úgy vélik, a tervezés összszervezeti támogatottsága viszonylag alacsony szintű, mint ahogy a felelősségre vonhatóság sem mindig biztosított.

Az informatikai támogatottság nagy eltéréseket mutat a mintában szereplő vállalatok gyakorlatában. Az átlagértékek alacsonyak. A tervezési adatok elérhetőek, mint ahogyan a törzsadatok megbízhatóságát sem érzik a szakemberek igazán kritikusnak. A dinamikus újratervezéshez szükséges értékelési szempontok egyértelműen a legalacsonyabb értékelést kapták. Bár rendelkezésre állnak a tervezést támogató megoldások, azok összetettsége sok kívánni valót hagy maga után, mint ahogyan azok integráltsága is gyenge. Ez pedig az adatok zökkenőmentes áramlását is gátolhatja. A folyamat eredményességét megragadó változók így nem meglepő módon kivétel nélkül alacsony értékelést kaptak.

Az 5. ábra a Walter-féle modell valamennyi értékelési szempontját összefoglaló jelleggel mutatja be. Legfejlettebbnek értékelték a kitöltő szakemberek (azaz az átlagos érték az adott értékelési változóban 4,5-nél nem volt kisebb) a szervezeti egységek közötti együttmüködés színvonalát, a pénzügyi tervezéssel meglévő összhangot, a

4. táblázat

A mintában szereplő cégek érettsége az IT-támogatás dimenzióban ( $N=33)$

\begin{tabular}{|c|c|c|c|c|c|c|c|c|c|}
\hline \multirow[b]{2}{*}{$\begin{array}{l}\text { Értékelési } \\
\text { dimenzió }\end{array}$} & \multirow[b]{2}{*}{ Változók } & \multicolumn{6}{|c|}{$\begin{array}{c}\text { Adott fejlettségi szinthez tartozó válla- } \\
\text { latok száma (db) mintánkban (ahol } 1 \text { a } \\
\text { legkevésbé érett, míg } 6 \text { a legfejlettebb } \\
\text { gyakorlatot mutatja) }\end{array}$} & \multirow{2}{*}{$\begin{array}{c}\text { Minta egésze } \\
\begin{array}{c}\text { Átlagos } \\
\text { fejlettségi szint }\end{array}\end{array}$} & \multirow[b]{2}{*}{ Szórás } \\
\hline & & 1 & 2 & 3 & 4 & 5 & 6 & & \\
\hline \multirow{5}{*}{ 占 } & Tervezési szoftver megléte, összetettsége & 12 & 4 & 7 & 3 & 0 & 7 & 2,9 & 1,9 \\
\hline & Informatikai tervezési rendszer integráltsága & 4 & 6 & 6 & 11 & 3 & 3 & 3,4 & 1,5 \\
\hline & Tervezési adatok elérhetősége & 2 & 3 & 5 & 4 & 7 & 12 & 4,4 & 1,6 \\
\hline & Tervezési adatok áramlásának automatikussága & 4 & 5 & 7 & 6 & 5 & 6 & 3,6 & 1,7 \\
\hline & Törzsadatok egységes meghatározottsága & 2 & 4 & 6 & 8 & 6 & 7 & 4,0 & 1,5 \\
\hline
\end{tabular}

Forrás: saját szerkesztés

\section{Az eredmények kiértékelése}

Felmérésünk tükrében a hazai vállalatok S\&OP gyakorlata a vizsgált érettségi modell folyamathatékonyság dimenziójában összefoglaló jelleggel a következőképpen jellemezhető. A vállalatok erőforrás-tervezési folyamatai jellemzően szabályozottak, erős az érintett szervezeti egységek közötti együttmüködés. Az erőforrásterveknek a pénzügyi tervvel való összekapcsolása viszonylag jó. Már kevésbé érzik fejlettnek a szakemberek ugyanakkor a tervezés szakmai tartalmát leíró értékelési változókat, így a kockázatok kezelésének szintjét, a kapacitástervezés kereslet és a kínálat kiegyenlítésére tett erőfeszítéseket, a feladatkörök egyértelmű definiáltságát és a felsővezetői támogatást. Úgy tünik, hogy a szervezeti feltételek jelentős része adott, az érintett szervezeti egységek erőfeszítései is magas szintűek. Ez ugyanakkor nem jár együtt megfelelő szintű szakmai és elsősorban informatikai támogatással, ami aztán alacsony eredményességhez vezet. Legkritikusabb, legkevésbé fejlett (azaz 3,5-ös értéknél nem nagyobb értékelést kapott) a hazai gyakorlat a tervezést támogató szoftver összetettségében, a tervezést támogató informatikai rendszer integráltságában, a tervezési folyamat automatizáltságában, a KPI-ok összehangoltságában, a ter- 
vezés szervezeti támogatottságában és a releváns külső szereplők bevonásában.

5. ábra

\section{A felmérésben szereplő vállalatok S\&OP gyakorlatának fejlettsége a Wagner-féle érettségi} modell változói mentén ( $\mathrm{N}=33$, válaszok átlagértékei, ahol 1 = legfejletlenebb gyakorlat; 6 = legfejlettebb gyakorlat)

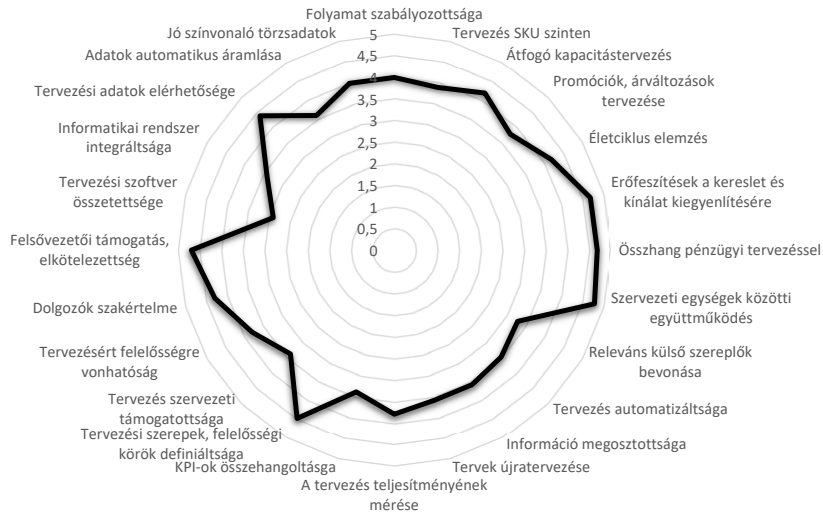

Forrás: saját szerkesztés

Kiszámoltuk a mintában szereplő vállalatok átfogó érettségi szintjét is. A folyamathatékonyság dimenzió valamennyi szempontjának értékeit átlagolva 4,18-at kaptunk, ami az érettségi modell konzisztens szintjének felel meg. Összességében a folyamat eredményességét megragadó dimenzió értékelési szempontjainak átlagértéke 3,58 lett, ez reaktív és a konzisztens fejlettségü gyakorlat között helyezhetö el. A szervezeti és emberi felkészültséget megragadó dimenzió mentén a konzisztens érettségi szakaszba tartoznak vállalataink, az ehhez tartozó értékelési szempontok átlaga 4,14. Végül, de nem utolsó sorban az informatikai támogatást értékelő dimenzió tekintetében mutatják a mintában szereplő vállalatok a legalacsonyabb érettségi szintet. Az értékelési szempontok átlaga ebben az esetben 3,66, ami a reaktív és konzisztens fejlettségi szintek közötti állapotra utal. Az egyes dimenziók összesített átlaga 3,89-es értéket ad, ami összességében közel konzisztens tervezési gyakorlatot tükröz.

Walter és szerzőtásai a modell kidolgozását követően (2014) maguk is végeztek kérdőíves felmérést. A kutatásban 88 vállalat vett részt. E vállalatok S\&OP érettsége e felmérés tükrében a reaktív állapotnak felel meg. Érdekes, hogy a négy dimenzió fejlettsége nagyon hasonló szinten van, az egyes dimenziók között alig van különbség.

A hazai felmérésben részt vevő vállalatok S\&OP fejlettsége gyakorlatilag egy szinttel magasabb. Ennek oka megítélésünk szerint egyrészt a két felmérés között eltelt idővel magyarázható, másrészt azzal, hogy a Walter-féle felmérésben túlreprezentáltak a közepes vállalatok, szemben a hazai felméréssel, melyben a nagyvállalatok aránya magas. Mint említettük az értékesítés- és müködéstervezés bevezetése minden vállalatméret esetében javasolható, de a hatékony, érett tervezési rendszer pozitív hatásai a vállalati méret növekedésével csak növekednek.
6. ábra

A felmérés mintájában szereplő vállalatok érettségi szintjének összehasonlítása a Walter és szerzőtársai által végzett felmérésben szereplő vállalatok érettségi szintjével $(\mathrm{N}=33$, illetve $\mathrm{n}=88$, a válaszok átlagértékei, ahol $1=$ legfejletlenebb gyakorlat; $6=$ legfejlettebb gyakorlat)

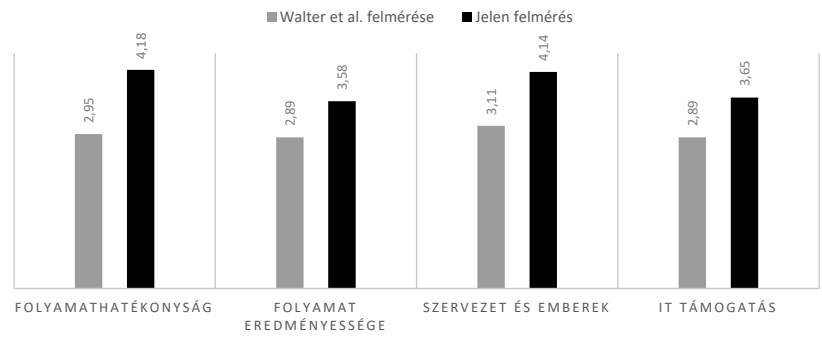

Forrás: saját szerkesztés

\section{Összegzés}

Évek óta a hazai szakmai közélet egyik kiemelten fontos kérdésköre vállalataink alacsony hatékonysága, termelékenysége (Boda, 2010; Reszegi, 2010; Békés, Halpern \& Muraközy, 2011) és azok a megoldások melyek révén az erősíthető, így például a lean menedzsment (Losonci, Demeter \& Jenei, 2010), vagy az innováció (Hámori \& Szabó, 2010; Halpern \& Muraközi, 2010; Hortoványi \& Balaton, 2016). A működést közvetlenül irányító tervezési, benne erőforrás-tervezési rendszereknek és azok gyakorlatának vizsgálata ugyanakkor marginális szerepet kap a hazai szakmai közéletben.

Tanulmányunk egy ilyen megoldást, az ún. értékesítés- és müködéstervezést állította a középpontba. Mint azt cikkünk bevezetőjében részletesen is tárgyaltuk, nemzetközi kutatások igazolták, hogy ez a viszonylag új tervezési és szervezeti egyeztetési folyamat jelentős mértékben képes hozzájárulni a vállalatok és azok ellátási láncainak hatékonyabb és eredményesebb müködéséhez. Ennek ellenére azt tapasztaltuk, hogy a hazai szakirodalom a témakört még nem ,fedezte fel”. Munkánk egyik célja ezért éppen az volt, hogy erre a hiányosságra felhívjuk a figyelmet, és az erőforrástervezési kérdéseket általában, a Sales \& Operations Planning eszközrendszerét pedig konkrétan is tárgyaljuk.

Az S\&OP-t a vállalatok és ellátási láncaik taktikai szintü tervezése során alkalmazott tervezési és szervezeti egyeztetési folyamatként értelmeztük, melynek célja, hogy egyensúlyt teremtsen a tényleges kereslet, a rendelkezésre álló erőforrások és az általuk biztosítható kínálat között oly módon, hogy támogassa az üzleti terv megvalósulását. Munkánk tárgyalta azokat az érettségi modelleket, melyek mentén a vállalatok aktuális gyakorlata felmérhető és értékelhető. Ezek közül empirikus kutatásunkban Walter és szerzőtársai (2014) modelljét alkalmaztuk. Ez a modell négy átfogó értékelési dimenzió mentén hat fejlettségi szintet különböztet meg. Kérdöíves felmérés alapján bemutattuk, milyen érettségi szinten vannak a mintában szereplö vállalatok.

Általánosan elmondhatjuk, hogy a mintában szereplő vállalatok S\&OP gyakorlata közepesen fejlett. Legkritiku- 
sabb elemei - melyek egyben a vállalati gyakorlat továbbfejlesztésének fö irányait is kijelölik - a következők:

- a tervezési folyamat integráltsága jellemzően csak a belső ellátási lánc tagokra terjed ki, a releváns külső, független ellátási lánc szereplők bevonása a tervezésbe még nem kielégítő,

- alacsony fejlettségü az S\&OP folyamat teljesítménymérésének a gyakorlata, ezért a folyamat során elkövetett hibákból való tanulás nem hatékony,

- bár az S\&OP folyamatának emberi aspektusai jellemzően kielégítő képet mutatnak, az integrált tervezési egyeztetési folyamatot dedikált tervezési szervezet jellemzően nem támogatja,

- leggyengébb pontja a rendszernek a folyamatok informatikai támogatottsága. Jellemzően hiányoznak a tervezést támogató integrált tervezési szoftverek, az APS-képességekkel bíró ERP-rendszerek még nem elterjedtek. A meglévő tervezési szoftverek integrációs foka így jellemzően nem kielégítő.

Kutatásunk korlátja a minta viszonylag kis elemszáma. Ugyanakkor ilyen témában hazai empirikus kutatás tudomásunk szerint még nem került publikálásra. Ezért kismintás felmérésünk eredményei is értékes bepillantást adnak a magyar vállalatok vonatkozó gyakorlatába, gazdagítják e vállalati gyakorlattal kapcsolatos hiányos ismereteinket, és lehetőséget teremtenek további cégek számára benchmarking tevékenység elvégzésére.

\section{Felhasznált irodalom}

Aquilano, N. J., Chase, R. B., Davis, M. M., \& Davis, M. M. (1991). Fundamentals of operations management. Homewood: Irwin.

Ávila, P., Lima, D., Moreira, D., Pires, A., \& Bastos, J. (2019). Design of a Sales and Operations Planning (S\&OP) process - case study. Procedia CIRP, 81, 1382-1387.

https://doi.org/10.1016/j.procir.2019.04.048

Barratt I., M. (2004). Understanding the meaning of collaboration in the supply chain. Supply Chain Management: An International Journal, 9(1), 30-42. https://doi.org/10.1108/13598540410517566

Békés, G., Halpern, L., \& Muraközy, B. (2011). A teremtő rombolás szerepe a vállalati termelékenység alakulásában Magyarországon. Közgazdasági Szemle, 58(2), 111-132.

Chikán A. \& Demeter K. (szerk.) (1999). Az értékteremtő folyamatok menedzsmentje - Termelés, szolgáltatás, logisztika. Budapest: Aula Kiadó.

Danese, P., Molinaro, M., \& Romano, P. (2018). Managing evolutionary paths in Sales and Operations Planning: key dimensions and sequences of implementation. International Journal of Production Research, 56(5), 2036-2053.

https://doi.org/10.1080/00207543.2017.1355119

De Toni, A. F., \& Zamolo, E. (2005). From a traditional replenishment system to vendor-managed inventory:
A case study from the household electrical appliances sector. International Journal of Production Economics, 96(1), 63-79.

https://doi.org/10.1016/j.ijpe.2004.03.003

Donáczi K. (2019). Sales \& Operations Planning - A hazai vállalati gyakorlat feltérképezése egy érettségi modell alapján (MSc-szakdolgozat). BCE Gazdálkodástudomány Kar, Logisztikai menedzsment MSc., Budapest.

Feng, Y., D’Amours, S., \& Beauregard, R. (2008). The value of sales and operations planning in oriented strand board industry with make-to-order manufacturing system: Cross functional integration under deterministic demand and spot market recourse. International Journal of Production Economics, 115(1), 189-209. https://doi.org/10.1016/j.ijpe.2008.06.002

Gelei A. (2009). Hálózat - A globális gazdaság kvázi szervezete. Vezetéstudomány, 40(1), 16-33.

Genin, P., Thomas, A., \& Lamouri, S. (2007). How to manage robust tactical planning with an APS (Advanced Planning Systems). Journal of Intelligent Manufacturing, 18(2), 209-221. https://doi.org/10.1007/s10845-007-0015-y

Grimson, J. A., \& Pyke, D. F. (2007). Sales and operations planning: an exploratory study and framework. The International Journal of Logistics Management, 18(3), 322-346. https://doi.org/10.1108/09574090710835093

György, B. (2010). Hatékony vállalat, hatékony társadalom. Vezetéstudomány, 41(7-8), 77-90.

Halpern, L., \& Muraközy, B. (2010). Innováció és vállalati teljesítmény Magyarországon. Közgazdasági Szemle, 57(4) 293-317.

Hámori, B., \& Szabó, K. (2010). A gyenge hazai innovációs teljesítmény intézményi magyarázatához. Vitaírás a nemzetközi innovációs versenyben való részvétel akadályairól. Közgazdasági Szemle, 57(10), 876-897.

Hortoványi, L., \& Balaton, K. (2016). A versenyképesség és az innováció vállalati szintű vizsgálata. Vezetéstudomány, 47(12), 38-45. https://doi.org/10.14267/VEZTUD.2016.12.04

Ivert, L. K. \& Jonsson, P. (2010). The potential benefits of advanced planning and scheduling systems in sales and operations planning. Industrial Management \& Data Systems, 110(5), 659 - 681. https://doi.org/10.1108/02635571011044713

Koltai T., Romhányi G., \& Tatay V. (2009). Optimalizálás bizonytalan paraméterekkel a termelés- és szolgáltatásmenedzsmentben. Vezetéstudomány, 40(különszám), pp.68-73.

Kovács Z. (2011). Ellátási láncok irányítási algoritmusai a sörjáték példáján. Vezetéstudomány, 42(11), 40-48.

Kristensen, J., \& Jonsson, P. (2018). Context-based sales and operations planning (S\&OP) research: a literature review and future agenda. International Journal of Physical Distribution \& Logistics Management, 48(1), 19-46. https://oi.org/10.1108/IJPDLM-11-2017-0352

Lapide, L. (2005). Sales and Operations Planning Part III: A diagnostic model. The Journal of Business Forecasting, 24(1), 13-16. 
László, D. (1977). A hatékonyságmérés és tervezés kérdései. Közgazdasági Szemle, 24(10), 1121-1136.

Lee, H. L., Padmanabhan, V., \& Whang, S. (1997). The bullwhip effect in supply chains. Sloan Management Review, 38, 93-102.

Lin, C. H., Hwang, S.-L. \& Wang, M.-Y. (2007). A reappraisal on advanced planning and scheduling systems. Industrial Management \& Data Systems, 107(8), 1212 -1226 . https://doi.org/10.1108/02635570710822822

Losonci, D., Demeter, K., \& Jenei, I. (2010). A karcsú (lean) menedzsment és a versenyképesség (The lean management and competitiveness). Vezetéstudomány, 41(3), 26-42.

Nemati, Y., Madhoshi, M., \& Safaei Ghadikolaei, A. (2017). The effect of Sales and Operations Planning (S\&OP) on supply chain's. Computers and Chemical Engineering, 104, 323-338. https://doi.org/10.1016/j.compchemeng.2017.05.002

Olhager, J., Rudberg, M., \& Wikner, J. (2001). Long-term capacity management: Linking the perspectives from manufacturing strategy and sales and operations planning. International Journal of Production Economics, 69(2), 215-225. https://doi.org/10.1016/S0925-5273(99)00098-5

Oliva, R., \& Watson, N. (2011). Cross-functional alignment in supply chain planning: A case study of sales and operations planning. Journal of Operations $M a-$ nagement, 29(5), 434-448. https://doi.org/10.1016/j.jom.2010.11.012

Oliver, Wight (2017). Oliver Wight's Crusade. Az Oliver Wight hivatalos oldala. Retrieved from https://www.oliverwight-americas.com/history

Pintácsi T. (2017). Sales \& Operations Planning - Fókuszban az érettségi modellek (MSc-szakdolgozat). BCE, Gazdálkodástudományi Kar, Logisztikai menedzsment MSc., Budapest.

Pedroso, C. B., da Silva, A. L., \& Tate, W. L. (2016). Sales and Operations Planning (S\&OP): Insights from a multi-case study of Brazilian Organizations. International Journal of Production Economics, 182, 213-229. https://doi.org/10.1016/j.ijpe.2016.08.035

Reszegi, L. (2010). Hatékony piac-hatékony vállalat? Vezetéstudomány, 41(7-8), 3-15.

Seeling, M. X., Scavarda, L. F., Thomé, A. M. T., \& Hellingrath, B. (2018). Sales and Operations Plan- ning Application: A Case Study in Brazil. In International Conference on Production and Operations Management Society (pp. 463-470). Wiesbaden: Springer.

Serfel A. (2018). A Schneider Electric SA Sales and Operations Planning gyakorlati értékelése az érettségi modellek tükrében (Szakdolgozat). BCE Gazdálkodástudományi Kar, Logisztika és Ellátási Lánc Menedzsment szakirányú továbbképzési szak, Budapest.

Singhal, J., \& Singhal, K. (2007). Holt, Modigliani, Muth, and Simon's work and its role in the renaissance and evolution of operations management. Journal of Operations Management. 25(2), 300-309.

Stadtler, H., \& Kilger, C. (2005). Supply chain management and advanced planning. Wiesbaden: Springer-Verlag.

Szalai A. (2013). A felső vezetés nélkülözhetetlen eszköze: az Értékesités és Müködéstervezés (MSc-szakdolgozat). BCE Gazdálkodástudományi Kar, Logisztikai menedzsment MSc., Budapest.

Tari E. (1987). A termelés irányításának láncolata iparvállalatainkban. Vezetéstudomány, 18(8) 9-15.

Tenner, A. R., \& DeToro, I. J. (1998). BPR - vállalati folyamatok újraformálása. Budapest: Müszaki Könyvkiadó.

Thomé, A. M., Scavarda, L. F., \& Suclla, N. (2012). Sales and operations planning and the firm performance. International Journal of Productivity and Performance Management, 61(4), 359-381. https://doi.org/10.1108/17410401211212643

Vereecke, A., Vanderheyden, K., Baecke, P., \& Van Steendam, T. (2018). Mind the gap-Assessing maturity of demand planning, a cornerstone of S\&OP. International Journal of Operations \& Production Management, 38(8), 1618-1639. https://doi.org/10.1108/IJOPM-11-2016-0698

Vörös J. (2018). Termelés- és szolgáltatásmenedzsment. Budapest: Akadémiai Kiadó.

Wagner, S. M., Ullrich, K. K., \& Transchel, S. (2014). The game plan for aligning the organization. Business Horizons, 57(2), 189-201.

https://doi.org/10.1016/j.bushor.2013.11.002

Wendler, R. (2012). The maturity of maturity model research: A systematic mapping study. Information and Software Technology, 54(12), 1317-1339. https://doi.org/10.1016/j.infsof.2012.07.007 
Melléklet:

Walter és szerzőtársai (2014) érettségi modelljének részletes bemutatása

\begin{tabular}{|c|c|c|c|c|c|c|}
\hline $\begin{array}{l}\text { Folyamathaté- } \\
\text { konyság }\end{array}$ & 1. szint: Fejletlen & 2. szint: Kezdetleges & 3. szint: Reaktiv & 4. szint: Konzisztens & 5. szint: Integrált & 6. szint: Proaktiv \\
\hline & $\begin{array}{l}\text { - nincs formalizált } \\
\text { tervezési folyamat } \\
\text { - nincs felülvizsgá- } \\
\text { lati meeting beüte- } \\
\text { mezve } \\
\text { - a kapacitások nin- } \\
\text { csenek figyelembe } \\
\text { véve } \\
\text { - nincsenek promó- } \\
\text { ciók és árváltozá- } \\
\text { sok tervezve } \\
\text { - nincs kockázatme- } \\
\text { nedzsment } \\
\text { - nincs terméké- } \\
\text { letciklus és új } \\
\text { termék bevezetése } \\
\text { tervezve } \\
\text { - nincsenek erőfe- } \\
\text { szítések, hogy a } \\
\text { keresletet és kíná- } \\
\text { latot összhangba } \\
\text { hozzák }\end{array}$ & $\begin{array}{l}\text { - látszólag forma- } \\
\text { lizált tervezési } \\
\text { folyamatok } \\
\text { - a meetingek nem } \\
\text { rutinszerüen van- } \\
\text { nak ütemezve } \\
\text { - a készlettartási } \\
\text { egységek és ter- } \\
\text { mékcsaládok nem } \\
\text { mindegyike van } \\
\text { a tervezési folya- } \\
\text { matban figyelembe } \\
\text { véve } \\
\text { - van már promó- } \\
\text { ció, árváltozás, } \\
\text { kapacitás, kocká- } \\
\text { zatmenedzsment, } \\
\text { új termék és élet- } \\
\text { ciklus tervezés, de } \\
\text { az S\&OP-nél nincs } \\
\text { figyelembe véve } \\
\text { - kisebb próbál- } \\
\text { kozások vannak } \\
\text { konszenzusra a } \\
\text { kereslet és kínálat } \\
\text { között, megfontol- } \\
\text { ják az egymástól } \\
\text { kapott informá- } \\
\text { ciókat } \\
\text { - többszörös keresle- } \\
\text { ti és kínálati tervek } \\
\text { vannak } \\
\end{array}$ & \begin{tabular}{|l} 
- közepesen for- \\
malizált tervezési \\
folyamatok és \\
tipikusan rutin \\
meetingek \\
- a legtöbb készlet- \\
tartási egység és \\
termékcsalád fi- \\
gyelembe van véve \\
a tervezés során \\
- a promóció, árvál- \\
tozás, kapacitás, \\
kockázatmenedzs- \\
ment, új termék és \\
életciklus tervezé- \\
se nem hatékony \\
- a keresleti oldal \\
egy szinkronizált, \\
összesített tervet \\
készít, a kínálati \\
oldal egy többé-ke- \\
vésbé összehangolt \\
tervet készít \\
- nincs összhang a \\
pénzügyi terve- \\
zéssel
\end{tabular} & $\begin{array}{l}\text { - erősen formalizált } \\
\text { tervezési folya- } \\
\text { matok } \\
\text { - minden SKU és } \\
\text { termékcsalád fi- } \\
\text { gyelembe van véve } \\
\text { a tervezés során } \\
\text { - a promóció, árvál- } \\
\text { tozás, kapacitás, } \\
\text { kockázatmenedzs- } \\
\text { ment, új termék } \\
\text { és életciklus } \\
\text { tervezése belsöleg } \\
\text { (a szervezetben) } \\
\text { hatékony } \\
\text { - a kereslet és kíná- } \\
\text { lat közösen készít } \\
\text { tervet, de még a } \\
\text { pénzügy nélkül } \\
\text { - a pénzügyi tervek } \\
\text { alapján döntenek } \\
\text { elsődlegesen, anél- } \\
\text { kül, hogy közösen } \\
\text { megvitatnák és } \\
\text { összehangolnák. }\end{array}$ & \begin{tabular}{|l} 
- belsőleg teljesen \\
formalizált terve- \\
zési folyamat \\
- rutin meetingek és \\
esemény alapúak \\
vegyesen \\
- a promóció, árvál- \\
tozás, kapacitás, \\
kockázatmenedzs- \\
ment, új termék és \\
életciklus tervezé- \\
se belsőleg haté- \\
kony, de külsőleg \\
nincs megtervezve \\
és figyelembe véve \\
- a kereslet, kínálati \\
és pénzügyi osz- \\
tály közösen készít \\
tervet az S\&OP-val \\
összhangban \\
- nincs interakció az \\
ellátási lánc más \\
szereplőivel
\end{tabular} & $\begin{array}{l}\text { - a tervezési folya- } \\
\text { mat formalizált } \\
\text { az ellátási láncon } \\
\text { keresztül } \\
\text { - eseményalapú } \\
\text { megbeszélések } \\
\text { - a promóció, árvál- } \\
\text { tozás, kapacitás, } \\
\text { kockázatmenedzs- } \\
\text { ment, új termék és } \\
\text { életciklus tervezés } \\
\text { belsőleg és külső- } \\
\text { leg is hatékonyan } \\
\text { van tervezve és } \\
\text { figyelembe véve } \\
\text { - minden releváns } \\
\text { információ belső- } \\
\text { leg és külsőleg is } \\
\text { meg van osztva, } \\
\text { hogy az átlátható- } \\
\text { ságot növeljék } \\
\text { - a külső partnerek } \\
\text { is részt vesznek a } \\
\text { folyamatok ösz- } \\
\text { szehangolásában, } \\
\text { hogy biztosítsák } \\
\text { a tervek megva- } \\
\text { lósítását, a profit } \\
\text { maximalizálást a } \\
\text { szervezetek mind- } \\
\text { egyikénél }\end{array}$ \\
\hline \multirow[t]{2}{*}{ eredményesség } & 1. szint: Fejletlen & 2. szint: Kezdetleges & 3. szint: Reaktiv & 4. szint: Konzisztens & 5. szint: Integrált & 6. szint: Proaktiv \\
\hline & $\begin{array}{l}\text { - minden tervezést } \\
\text { manuálisan csi- } \\
\text { nálnak } \\
\text { - az információ csak } \\
\text { részben elérhető } \\
\text { - sok hiányosság van } \\
\text { - gyakori újraterve- } \\
\text { zés szükséges } \\
\text { - nincsenek tervezé- } \\
\text { si meetingek } \\
\text { - nincs terv össze- } \\
\text { hangolás } \\
\text { - a tervezés ha- } \\
\text { tékonysága és } \\
\text { hatásossága nincs } \\
\text { mérve } \\
\text { - nincs KPI, ami } \\
\text { mérné a tervezés } \\
\text { teljesítményét } \\
\text { - nincsenek telje- } \\
\text { sítménykövetési } \\
\text { erőfeszítések }\end{array}$ & $\begin{array}{l}\text { - az információ } \\
\text { decentralizált nyil- } \\
\text { vántartása miatt, } \\
\text { sok hiányosság van } \\
\text { az információ-elö- } \\
\text { készítésben } \\
\text { - a szervezetek } \\
\text { között sok a súrló- } \\
\text { dási veszteség az } \\
\text { információátadás } \\
\text { közben } \\
\text { - a meetingen } \\
\text { résztvevők nem } \\
\text { jogosultak döntést } \\
\text { hozni } \\
\text { - az alacsony terve- } \\
\text { zési összehangolt- } \\
\text { ság miatt gyakori } \\
\text { újratervezés szük- } \\
\text { séges } \\
\text { - az alapvető KPI- } \\
\text { ok definiáltak, de } \\
\text { csak ritkán foglal- } \\
\text { koznak velük } \\
\text { - a KPI-ok nincse- } \\
\text { nek összehangolva } \\
\text { az egyes részlegek } \\
\text { között, se az üzleti } \\
\text { stratégiával, se a } \\
\text { bónusz rendszerrel }\end{array}$ & $\begin{array}{l}\text { - részben centra- } \\
\text { lizált információ } \\
\text { tárolás csökkenti a } \\
\text { felesleges munkát } \\
\text { az információ-elö- } \\
\text { készítésben } \\
\text { - közepes a súrló- } \\
\text { dási veszteségek } \\
\text { száma, a részlegek } \\
\text { közti információá- } \\
\text { tadásban } \\
\text { - a kezdetleges terv } \\
\text { összehangoltság } \\
\text { miatt gyakoriak az } \\
\text { újratervezések } \\
\text { - a meetingen részt- } \\
\text { vevők általában } \\
\text { hozhatnak dönté- } \\
\text { seket }\end{array}$ & $\begin{array}{l}\text { - a releváns infor- } \\
\text { mációk automati- } \\
\text { kusan meg vannak } \\
\text { osztva és elöké- } \\
\text { szítve } \\
\text { - nagyon kicsik a } \\
\text { súrlódási költségek } \\
\text { a részlegek közötti } \\
\text { információ átadás } \\
\text { során } \\
\text { - a meetingek } \\
\text { formalizáltak és } \\
\text { ennek megfelelöen } \\
\text { vannak lefolytatva } \\
\text { (döntési jogkörrel } \\
\text { bíró résztvevökkel) } \\
\text { - megfelelö ter- } \\
\text { vezésnek kö- } \\
\text { szönhetően nem } \\
\text { gyakoriak az } \\
\text { újratervezések } \\
\text { - a tervezéssel kap- } \\
\text { csolatos erőfeszíté- } \\
\text { sek részben megfe- } \\
\text { lelnek a szervezeti } \\
\text { követelményeknek } \\
\text { - strukturált mükö- } \\
\text { dést állítottak fel } \\
\text { az S\&OP mükö- } \\
\text { désére } \\
\text { - rendszeres a ri- } \\
\text { portálás és a telje- } \\
\text { sítmény nyomon } \\
\text { követése } \\
\end{array}$ & $\begin{array}{l}\text { - az emberek csak } \\
\text { olyan információ- } \\
\text { kat kapnak, amikre } \\
\text { szükségük van } \\
\text { - nincsenek súrlódá- } \\
\text { si veszteségek az } \\
\text { egyes szervezeti } \\
\text { egységek között } \\
\text { - a meetingek kivé- } \\
\text { tel- és eseményala- } \\
\text { púak } \\
\text { - a megfelelő terv } \\
\text { összehangoltság- } \\
\text { nak köszönhetően } \\
\text { az újratervezés } \\
\text { ritkán szükséges } \\
\text { - a tervezésbe } \\
\text { fektetett energia } \\
\text { tökéletes elegendő } \\
\text { a szervezet igé- } \\
\text { nyeihez } \\
\text { - a KPI-ok teljes } \\
\text { összehangoltsága } \\
\text { jellemző mind a } \\
\text { szervezetek között, } \\
\text { az üzleti stratégi- } \\
\text { ával és a bónusz } \\
\text { rendszerekkel } \\
\text { egyaránt } \\
\text { - belső S\&OP } \\
\text { benchmark rend- } \\
\text { szertelenül van } \\
\text { elvégezve }\end{array}$ & $\begin{array}{l}\text { - a külső partnerek } \\
\text { integrálva vannak } \\
\text { rendszer szintjén } \\
\text { EDI-ként, hogy } \\
\text { elkerüljék a feles- } \\
\text { leges adatbevitelt } \\
\text { - az S\&OP mee- } \\
\text { tingen kizárólag } \\
\text { esemény alapúak } \\
\text { és leginkább } \\
\text { online-ak, hogy } \\
\text { elkerüljék a feles- } \\
\text { leges utazásokat } \\
\text { - az ellátási lánc sze- } \\
\text { replők részt vesz- } \\
\text { nek az összehango- } \\
\text { lás folyamatában, } \\
\text { hogy elkerüljék az } \\
\text { újraütemezéseket, } \\
\text { például a beszállí- } \\
\text { tói kapacitás korlá- } \\
\text { tozások miatt. } \\
\text { - a KPI-ok telje- } \\
\text { sítménymérése } \\
\text { az ellátási lánc } \\
\text { érintettek felé is } \\
\text { érvényben van és a } \\
\text { fizetési } \\
\text { feltételekbe be- } \\
\text { építve. } \\
\text { - belső és külső } \\
\text { S\&OP benchmark } \\
\text { rendszeresen } \\
\text { végrehajtva } \\
\end{array}$ \\
\hline
\end{tabular}




\begin{tabular}{|c|c|c|c|c|c|c|}
\hline \multirow[t]{2}{*}{$\begin{array}{c}\text { Személyek és } \\
\text { szervezet }\end{array}$} & 1. szint: Fejletlen & 2. szint: Kezdetleges & 3. szint: Reaktivv & 4. szint: Konzisztens & 5. szint: Integrált & 6. szint: Proaktiv \\
\hline & $\begin{array}{l}\text { - a szerepek nin- } \\
\text { csenek tisztázva } \\
\text { és a felelősségi } \\
\text { körök a tervezési } \\
\text { tevékenységekkel } \\
\text { és feladatokkal } \\
\text { kapcsolatban } \\
\text { - nincs tervezési } \\
\text { osztály alapítva } \\
\text { - a dolgozók nem } \\
\text { értik a szükséges- } \\
\text { ségét és követel- } \\
\text { mény rendszerét az } \\
\text { S\&OP-nak } \\
\text { - nem hatékony a } \\
\text { tervezési know- } \\
\text { how } \\
\text { - nincs vezetői } \\
\text { elkötelezettség }\end{array}$ & $\begin{array}{l}\text { - hiányosságok } \\
\text { vannak a tervezési } \\
\text { szervezetben (nin- } \\
\text { csenek letisztázott } \\
\text { pozíció leírások, az } \\
\text { üzletvitellel nincs } \\
\text { összhangban) } \\
\text { - a dolgozók nem } \\
\text { vonhatók felelös- } \\
\text { ségre a küldött } \\
\text { terveikért és telje- } \\
\text { sítményükért } \\
\text { - alacsony szakérte- } \\
\text { lemmel, fogékony- } \\
\text { sággal és attitüddel } \\
\text { rendelkeznek az } \\
\text { S\&OP-ról a dol- } \\
\text { gozók } \\
\text { - hiányzik az elkö- } \\
\text { telezettség és a } \\
\text { felsővezetői támo- } \\
\text { gatás }\end{array}$ & $\begin{array}{l}\text { - a szerepek és } \\
\text { felelösségi körök } \\
\text { le vannak tisztáz- } \\
\text { va, de nincsenek } \\
\text { sikeresen beültetve } \\
\text { a szervezetben } \\
\text { - nincs dedikált } \\
\text { S\&OP felelős } \\
\text { - a dolgozók részben } \\
\text { felelösségre von- } \\
\text { hatók a tervezésért } \\
\text { és a teljesítményért } \\
\text { - közepes szintü } \\
\text { elkötelezettség és } \\
\text { felsővezetői támo- } \\
\text { gatás jellemző }\end{array}$ & $\begin{array}{l}\text { - új tervezési osztály } \\
\text { létrejön dedikált } \\
\text { S\&OP felelössel } \\
\text { - az S\&OP fele- } \\
\text { lösségi körök le } \\
\text { vannak tisztázva, } \\
\text { részletes munka- } \\
\text { köri leírással, amit } \\
\text { a dolgozók ismer- } \\
\text { nek és betartanak } \\
\text { - elegendő tudással } \\
\text { rendelkeznek, } \\
\text { hogy magasabb } \\
\text { S\&OP tevékeny- } \\
\text { ségeket vigyenek } \\
\text { véghez } \\
\text { - kiváló elkötelezett- } \\
\text { ség és felsővezetői } \\
\text { támogatás }\end{array}$ & $\begin{array}{l}\text { - az egész tervezési } \\
\text { osztály összhang- } \\
\text { ban van az üzlet- } \\
\text { vitellel } \\
\text { - a tervezés agilis } \\
\text { és lehetővé tesz } \\
\text { gyors visszajelzé- } \\
\text { seket a nem várt } \\
\text { módosításokra } \\
\text { - elegendő tudás, } \\
\text { hogy további } \\
\text { tervezéssel kap- } \\
\text { csolatos tevékeny- } \\
\text { ségeket hajtsanak } \\
\text { végre, mint kocká- } \\
\text { zatelemzés } \\
\text { - kiváló elkötelezett- } \\
\text { ség és felsővezetői } \\
\text { támogatás }\end{array}$ & $\begin{array}{l}\text { - új szervezeti struk- } \\
\text { túra kialakítása } \\
\text { dedikált S\&OP } \\
\text { folyamat felelössel, } \\
\text { aki koordinálja a } \\
\text { tervezési folyama- } \\
\text { tot az egész ellátási } \\
\text { láncban } \\
\text { - a dolgozók és a } \\
\text { top menedzsment } \\
\text { magasan elkötele- } \\
\text { zettek és töreked- } \\
\text { nek a folyamatos } \\
\text { fejlesztésre } \\
\text { - minden partner } \\
\text { vállalat top me- } \\
\text { nedzsmentje támo- } \\
\text { gatja és részt vesz } \\
\text { az S\&OP imple- } \\
\text { mentálásban }\end{array}$ \\
\hline \multirow[t]{2}{*}{ IT-támogatás } & 1. szint: Fejletlen & 2. szint: Kezdetleges & 3. szint: Reaktiv & 4. szint: Konzisztens & 5. szint: Integrált & 6. szint: Proaktiv \\
\hline & $\begin{array}{l}\text { - nincs tervezési } \\
\text { rendszer } \\
\text { - különböző tábláza- } \\
\text { tok használata } \\
\text { - törzsadatok nem } \\
\text { pontosan defini- } \\
\text { áltak } \\
\text { - nincs harmónia a } \\
\text { törzsadatokban a } \\
\text { szervezeten belül }\end{array}$ & \begin{tabular}{|} 
- elkülönített keres- \\
let és kínálat ter- \\
vezési rendszerek, \\
limitált funkciona- \\
litásokkal, ame- \\
lyek beépíthetőek \\
- nincs integrált ke- \\
resleti és müködési \\
tervezési szoftver \\
- a tervező rendsze- \\
reknek nincs hoz- \\
záférésük minden \\
releváns tervezöi \\
adathoz \\
- nem következete- \\
sen vannak defini- \\
álva a törzsadatok \\
- a törzsadatok \\
nincsenek harmo- \\
nizálva a szerveze- \\
ten belül
\end{tabular} & $\begin{array}{l}\text { - kereslettervező } \\
\text { szoftver és több- } \\
\text { funkciós gyártási } \\
\text { tervezörendszerek } \\
\text { állnak rendelke- } \\
\text { zésre, fejlettebb } \\
\text { funkciókkal, } \\
\text { amik statisztikai } \\
\text { elemzésekre } \\
\text { is alkalmasok } \\
\text { (egymást követő) } \\
\text { optimalizálást tesz } \\
\text { lehetővé } \\
\text { - az információt más } \\
\text { rendszerekből ma- } \\
\text { nuálisan kell, hogy } \\
\text { felvigyék vagy } \\
\text { feltöltsék (nincs } \\
\text { interfész) } \\
\text { - a tervezési rend- } \\
\text { szereknek hozzá- } \\
\text { férésüknek kell, } \\
\text { hogy legyen a } \\
\text { releváns tervada- } \\
\text { tokhoz } \\
\text { - a törzsadatok } \\
\text { következetesen } \\
\text { vannak definiál- } \\
\text { va, de nincsenek } \\
\text { harmonizálva a } \\
\text { szervezeten belül } \\
\end{array}$ & $\begin{array}{l}\text { - több funkciós } \\
\text { APS-rendszerek } \\
\text { vannak haszná- } \\
\text { latban } \\
\text { - S\&OP munka- } \\
\text { asztal és szoftver } \\
\text { használata, ahol a } \\
\text { munkafolyamatot } \\
\text { nyomon tudják } \\
\text { követni } \\
\text { - minden tervezési } \\
\text { modul és eszkö- } \\
\text { zök össze vannak } \\
\text { linkelve egy } \\
\text { interfészen ke- } \\
\text { resztül a mögöttes } \\
\text { ERP-rendszerekkel } \\
\text { és hozzáférésük } \\
\text { van ezáltal minden } \\
\text { tervezési adathoz } \\
\text { - a tervezési beál- } \\
\text { lítások automati- } \\
\text { kusan érvényesek } \\
\text { minden modulra } \\
\text { - a törzsadatok } \\
\text { következetesen } \\
\text { vannak definiálva } \\
\text { és harmonizálva a } \\
\text { szervezeten belül }\end{array}$ & $\begin{array}{l}\text { - a rendszerek folya- } \\
\text { matosan nyomon } \\
\text { követik a terveket } \\
\text { és figyelmezteté- } \\
\text { seket küldenek, ha } \\
\text { nem várt eltérés } \\
\text { tapasztalható } \\
\text { - a szoftver megol- } \\
\text { dási javaslatot is } \\
\text { tud nyújtani, ha } \\
\text { kérik } \\
\text { - egy teljesen in- } \\
\text { tegrált rendszert } \\
\text { használnak } \\
\text { - a törzsadatok } \\
\text { proaktívan vannak } \\
\text { belsőleg kezelve, } \\
\text { de kifelé nem }\end{array}$ & $\begin{array}{l}\text { - szoftvertámogatás } \\
\text { CPFR, TPM és } \\
\text { más átláthatóságot } \\
\text { biztosító eszközök, } \\
\text { amik integrálják } \\
\text { az ellátási lánc } \\
\text { szereplöket egy } \\
\text { IT-infrastruktú- } \\
\text { rában } \\
\text { - az IT-rendszerek } \\
\text { teljesen összehan- } \\
\text { goltan müködnek } \\
\text { az egész ellátási } \\
\text { láncon belül } \\
\text { - minden releváns } \\
\text { információ elér- } \\
\text { hető (beleértve a } \\
\text { kapacitás adatokat } \\
\text { harmadik felektöl: } \\
\text { albeszállítóktól } \\
\text { stb.) } \\
\text { - a törzsadatok } \\
\text { következetesen } \\
\text { vannak definiálva } \\
\text { és harmonizálva } \\
\text { az egész ellátási } \\
\text { láncon belül }\end{array}$ \\
\hline
\end{tabular}

